\title{
Associated Factors with Pain and Disability in Patients With Knee Osteoarthritis
}

\section{Diz Osteoartriti Olan Hastalarda Ağrı ve Özürlülükle ilişskili Faktörler}

\author{
Duygu Geler Külcü1, Burcu Yanık2, Hakan Atalar³, Gülçin Gülşen¹ \\ 1Yeditepe Üniversitesi Hastanesi, Fizik Tedavi ve Rehabilitasyon Anabilim Dalı, istanbul, Turkey \\ 2Fatih Üniversitesi Tıp Fakültesi, Fizik Tedavi ve Rehabilitasyon Anabilim Dalı, Ankara, Turkey \\ 3Fatih Üniversitesi Tıp Fakültesi, Ortopedi ve Travmatoloji Anablim Dalı, Ankara, Turkey
}

\begin{abstract}
Objective: To assess factors associated with pain and functional level in patients with knee osteoarthritis (OA).

Materials and Methods: Patients with knee OA $(n=161)$, with a mean age of $62.4 \pm 8.7$ yrs were studied. Age, sex, body mass index (BMI), education level, smoking habit, regular physical activity habit, symptom duration were recorded. KellgrenLawrence scores were calculated in anterio-posterior and lateral knee radiographs. Functional level of patients were assessed by Western Ontario and McMaster Universities Osteoarthritis Index (WOMAC) and pain severity of the patients were assessed by Visual Analoge Scale (VAS).

Results: The BMI was positively correlated with mean scores of WOMAC pain, joint stiffness and daily living activities subscores $(r=0.592, r=0.634$, and $r=0.749$, respectively). Education level was inversely correlated with mean scores of WOMAC pain, joint stiffness and daily living activities subscores $(r=-0.394, r=-0.345$, and $r=-0.352$, respectively). Kellgren-Lawrence scores of anteriorposterior and lateral view radiographs were found to be correlated with age and symptom duration $(r=0,263, p=0,001$ and $r=0,339, p=0,016$, respectively). No relationship was found between pain VAS scores and any assessed factors. When WOMAC subscale scores and VAS scores were compared according to gender, WOMAC pain scores were found higher in females $(p=0.024)$. No correlation was found between remainder factors and scores of the three sections of WOMAC.

Conclusion: The BMI is the most important factor associated with functional level and pain severity of patients with KOA. Patients must be encouraged to loose weight in order to decrease symptom and disease severity.

(Turk J Rheumatol 2010; 25: 77-81)

Key words: Knee, osteoarthritis, pain, disability
\end{abstract}

Received: 07.06.2008

Accepted: 16.07.2008

\section{Özet}

Amaç: Diz osteoartriti (OA) olan hastalarda ağrı ve fonksiyonel düzeyle ilișkili etkenleri belirlemektir.

Yöntem ve Gereçler: Diz OA tanısı alan 161 hasta çalıșmaya alındı. Hastaların yas ortalaması $62.4 \pm 8.7$ yıl olup ortalama semptom süresi $43.76 \pm 26.6$ aydı. Hastaların yaș, cinsiyet, vücut kütle indeksi, eğitim düzeyi, sigara ve düzenli egzersiz alıșkanlığı ve semptom süreleri kaydedildi. Ön-arka ve lateral diz grafilerinde Kellgren-Lawrence skorları hesaplandı. Hastaların fonksiyonel düzeyi Western Ontario ve McMaster Üniversitesi Osteoartrit Indeksi (WOMAC) ile, ağrı șiddeti Görsel Ağrı Skalası (GAS) ile değerlendirildi.

Bulgular: Vücut kütle indeksi ile WOMAC ağrı skoru $(r=0.592$, $p=0.0001)$, WOMAC eklem sertliği skoru $(r=0.634, p=0.0001)$ ve WOMAC günlük yașam aktiviteleri skoru ( $r=0.749, p=0.0001)$ arasında ilișki saptandı. Eğitim düzeyi ile WOMAC ağrı skoru $(r=-0.394, p=0.001)$, WOMAC eklem sertliği skoru $(r=-0.345$, $p=0.004)$, ve WOMAC günlük yașam aktiviteleri skoru $(r=-0.352$, $\mathrm{p}=0.003$ ) arasında ters ilișki saptandı. Kellgren-Lawrence skoru (ön-arka ve yan grafi) ile GAS skoru ve her üç WOMAC skoru arasında ilișki saptanmadı ( $p>0.05)$. Kellgren-Lawrence ön-arka ve yan grafi skorları yaș ve semptom süresiyle ilișkili bulundu (sırasıyla $r=0.263, p=0.001$ ve $r=0.339, p=0.016$ ). GAS skoru ile herhangi bir parametre arasında ilișki saptanmadı. WOMAC alt grup skorları ve GAS skoru cinsiyete göre karșılaștırıldığında WOMAC ağrı skorunun bayanlarda daha yüksek olduğu saptandı $(p=0.024)$. Geri kalan faktörlerle WOMAC alt grup skorları arasında korelasyon saptanmadı.

Sonuç: Vücut kütle indeksi, diz OA olan hastalarda fonksiyonel düzey ve ağrı șiddetiyle ilișkili en önemli faktördür. Hastalar, semptom ve hastalık șiddetini azaltmak açısından kilo vermeye teșvik edilmelidirler.

(Turk J Rheumatol 2010; 25: 77-81)

Anahtar sözcükler: Diz, osteoartrit, ağrı, özürlülük

Alındığı Tarih: 07.06.2008 Kabul Tarihi: 16.07.2008

Address for Correspondence: Dr. Duygu Geler Külcü, Yeditepe Üniversitesi Hastanesi, Fizik Tedavi ve Rehabilitasyon Anabilim Dalı, istanbul, Turkey Phone: +90 2165784108 Fax: +90 2164678869 E-mail: d_geler@yahoo.com.tr 


\section{Introduction}

Osteoarthritis (OA) is the most prevalent rheumatological disorder and frequently affects the weight-bearing joints such as the hips and knees (1). Cartilage degeneration and inflammation stimulate new bone (spur) formation around the joint (2). These degenerative changes cause pain, stiffness and swelling (1) that result in chronic disease and disability with advanced age and seriously alter the quality of life (3). The degree of pain and functional loss are the factors that guide the selection of treatments for OA of the knee, which include the use of non-steroidal anti-inflammatory drugs (NSAIDs), exercising, physical therapy, and knee arthroplasty $(4,5)$.

It is, therefore, very important to identify the factors causing the pain and disability in each presenting case in order to select the correct mode of treatment to impede the advance of the disease. The aim of this cross-sectional study was to investigate the factors associated with the level of pain and disability in patients with OA of the knee.

\section{Materials and Methods}

Patients attending the Physical Medicine and Rehabilitation outpatient clinic with complaints of knee pain were investigated via the patient's history, physical examination and radiographic imaging. Diagnosis of OA of the knee was made according to the criteria of the American College of Rheumatology (ACR) (6). The criteria for exclusion from this study were: inflammatory knee disorders, metabolic bone disease, history of knee trauma, previous knee surgery, previous intra-joint injections, and use of NSAIDs in the past three months. A total of 161 patients were included in the study. Demographic data, including age, gender, height, body weight, educational level, smoking habit, regularity of physical exercise, and duration of pain were recorded. Body mass index $\left(\mathrm{BMI}, \mathrm{kg} / \mathrm{m}^{2}\right.$ ) was calculated for each patient. The study was approved by the university ethical committee, and all patients signed an informed consent form.

Knee X-ray images were made front-to-back while standing and laterally with the knee at 30 degree flexion. These were evaluated independently by two clinicians, and scored between 0 and 4 with respect to the KellgrenLawrence criteria (7). In cases of disparity, the clinicians reassessed the $\mathrm{X}$-ray images together.

Pain intensity and functional level were scored, respectively, according to Visual Pain Scale (VAS) (no pain=0, unbearable pain $=10$ ) and Western Ontario and McMaster Universities Osteoarthritis Index (WOMAC). WOMAC subscores for pain (WOMAC part A), joint stiffness (WOMAC part B) and daily living activities (WOMAC part C) were calculated separately.

\section{Statistical Analyses:}

The SPSS 11.0 package was used for statistical analyses. Spearman correlation coefficient was calculated to investigate any correlation between pain and functional level of the joint and the demographic characteristics and KellgrenLawrence scores. Statistical differences between genders were evaluated through the Mann-Whitney $U$ test.

\section{Results}

The mean age of the patients was $62.4 \pm 8.7$ years, and 121 of the patients were female. The mean BMI was $26.7 \pm 12.2 \mathrm{~kg} / \mathrm{m}^{2}\left(18.66-43.5 \mathrm{~kg} / \mathrm{m}^{2}\right)$, and the mean pain duration was $43.76 \pm 26.6$ months. The demographic details of the patients are given in Table 1. Positive correlations were determined between $\mathrm{BMI}$ and WOMAC pain score $(r=0.592, p=0.0001)$, WOMAC joint stiffness score $(r=0.634, p=0.0001)$ and WOMAC daily living activities score $(r=0.749, p=0.0001)$. Inverse correlations were determined between educational level and WOMAC pain score $(r=-0.394, p=0.001)$, WOMAC joint stiffness score $(r=-0.345, p=0.004)$, and WOMAC daily living activities score $(r=-0.352, p=0.003)$. No correlation was observed

Table 1. Demographic characteristics and outcome parameters of the patients $(n=161)$

Age (years)

Body mass index $\left(\mathrm{kg} / \mathrm{m}^{2}\right)$

Disease duration (months)

Regular aerobic exercise

Smoking habit (\%)

Kellgren-Lawrence Score (median)

Education (\%)

Primary $(n=59)$

Secondary $(n=35)$

High School $(n=32)$

University $(n=12)$

VAS score

WOMAC-A score (median)

WOMAC-B score (median)

WOMAC-C score (median)
$62.4 \pm 8.7(42-83)$

$26.7 \pm 12.2(18.6-43.5)$

$43.8 \pm 26.6(6-324)$

$12.5 \%(n=20)$

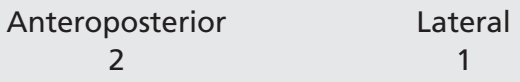
$42.8 \%$
$25.4 \%$
$23.2 \%$
$8.7 \%$
$6.6 \pm 1.4(2-10)$
$12(1-19)$
$5(0-11)$
$41(6-65)$

AS: Visual Analogue Scale, WOMAC: Western Ontario and McMaster Universities Osteoarthritis Index Values are presented as median or mean \pm standard deviation (minimum-maximum) 
between the Kellgren-Lawrence scores for the anteriorposterior and lateral X-rays, the VAS score and all three WOMAC subscores $(p>0.05)$. There were statistically significant relationships between the Kellgren-Lawrence scores and age $(r=0.263, p=0.001)$ and duration of symptoms $(r=0.339, p=0.016)$. No relationship was observed between the VAS score and any of the parameters. When the WOMAC subscores and the VAS score were compared according to gender, the WOMAC pain score was found to be higher in the female patients $(p=0.024)$. There were no statistically significant differences between genders in terms of age $(p=0.09)$, symptom duration $(p=0.904)$ and BMI ( $p=0.135)$, as shown in Table 2.

\section{Discussion}

In this study, we investigated the possible causative factors associated with pain intensity and functional level in patients diagnosed with OA of the knee. Educational level and BMI were found to be associated with the pain and functional level of the joint. Obesity has been shown to be as a risk factor for OA of the knee (11-16). It is known that excess body weight contributes to the development of OA by increasing the stress on the weightbearing joints as well as through metabolic effects $(15,16)$. Extra physical load causes tearing and fragmentation of the cartilage, thereby facilitating the development of OA (15). At the same time, the biomechanics of the joints are adversely affected by the abnormal loading, necessitating more demand from the quadriceps muscles. In this investigation, the patients were overweight on the basis of BMI values and did not perform regular aerobic exercises.

Although a positive correlation between BMI and WOMAC pain scores was demonstrated, a similar relationship between BMI and VAS scores was not observed. This disagreement in the results is probably due to the different scoring procedures. Using the WOMAC pain questionnaire, patients verbally score the pain severity while performing specific activities like walking on a flat surface or climbing up and down stairs. With the VAS, patients are asked to score pain they experience during a specific general daily activity on a scale of 1 to 10 . However, since patients are sitting while responding and not experiencing pain at that moment, they are more likely to underscore the pain level for a general daily activity despite having complained of severe pain when, for example, using the stairs for the purposes of WOMAC scoring.

Inverse relationships were observed between educational level and pain, joint stiffness and daily living activities. Disagreement between the change observed in WOMAC scores and results on objective parameters like range of motion have been reported (18). The arguments put forward included the possible dependence of the rating of pain experienced by the patients on psychological status, personality and the means developed to cope with the pain. Hence, another factor to be considered can be the educational level of the patient, such that those patients with lower educational level could be exaggerating or finding it difficult to describe the pain experienced. Therefore, we believe that more objective methods should be developed to assess the pain level and hence the disability of the patients.

Disagreements have also been observed in the results of different studies on the relationship of cigarette smoking and OA of the knee. While some have concluded that there is cartilage loss in association with smoking, which causes OA development $(19,20)$, others have proposed a protective role of smoking against the development of OA (21-24). Although the mechanism of the proposed protective effect of smoking is not clearly understood, the reorganization by nicotine of the activation of the collagen-glycosaminoglycan synthesis in the chondrocytes has been demonstrated by Gullahorn et al. (25). However, Wilder and Ark (26) did not see a relationship between cigarette smoking and the radiological evidence of the grade of OA of the knee. In the present study, no relationship was determined between the Kellgren-Lawrence scores of the X-ray images and the pain level and functional loss. This result may be due to the paucity of smokers among our patients.

In this study, radiological grading of OA correlated with the patient's age as well as the duration of the disease, a finding which once again has shown the progressive nature of OA and the necessity of taking early measures to impede the advance of the disease (27). A survey of the literature has shown disagreements between the

\begin{tabular}{lcccccc}
\multicolumn{2}{l}{ Table 2. Comparison of patients according to gender } \\
\hline Age (years) & $\begin{array}{c}\text { BMI } \\
\left(\mathbf{k g} / \mathbf{m}^{2}\right)\end{array}$ & VAS score & $\begin{array}{c}\text { WOMAC-A score } \\
\text { (median) }\end{array}$ & $\begin{array}{c}\text { WOMAC-B score } \\
\text { (median) }\end{array}$ & $\begin{array}{c}\text { WOMAC-C score } \\
\text { (median) }\end{array}$ \\
\hline Female & $61.8 \pm 9.1$ & $26.5 \pm 13.0$ & $6.7 \pm 1.5$ & 12 & 5 & 41 \\
Male & $(42-83)$ & $(21.5-43.5)$ & $(2-10)$ & $(1-19)$ & $(0-11)$ & $(6-65)$ \\
& $64.0 \pm 7.2$ & $27.2 \pm 9.4$ & $6.4 \pm 1.3$ & 6 & 4 & 32 \\
$\mathrm{P}$ & $(50-80)$ & $(18.7-41.9)$ & $(5-8)$ & $(4-17)$ & $(0-8)$ & $(6-60)$ \\
\hline
\end{tabular}

BMI: Body mass index, VAS: Visual Analogue Scale, WOMAC: Western Ontario and McMaster Universities Osteoarthritis Index Values are presented as median or mean \pm standard deviation (minimum-maximum). 
results of clinical and radiological investigations. In general, however, these results are comparable to the results of this study, in which radiological scoring of the disease did not correlate with pain intensity or functional loss in the joint (28-31). The reasons for these observations could have resulted from examination of only the tibiofemoral joint $(30,31)$. However, the results of investigation of both the tibiofemoral and the patellofemoral joints in the study presented here did not show a correlation between the Kellgren-Lawrence scores and the functional level or pain intensity. Szebenyi B. et al. (29), having also investigated the tibiofemoral and patellofemoral joints, observed that the patients with structural changes in both joints experienced more pain and functional limitations as compared to those who had deformations only in a single joint type. In the present study, there were a few cases with structural deformity in only a single compartment. Another and important conclusion of the Szebenyi et al. (29) study was the determination of correlations between different radiological findings of osteophytes, joint space narrowing and subchondral sclerosis of the knee, despite the failure to demonstrate a correlation between the Kellgren-Lawrence scores and pain intensity or functional level of the joint.

It has been shown in a recent study that the KellgrenLawrence score is not related to the VAS or the WOMAC score but that it is important for the follow-up on the progress of the disease (32). Direct X-ray radiography is a suboptimal technique for demonstrating pathologies like synovitis or bone marrow edema, which underlie the joint pain. Torres et al. (33) demonstrated that pain intensity correlated with erosion in subchondral bone, bone marrow lesions, synovitis, effusion, and meniscal tear, which are not demonstrable with direct X-ray imaging. Further, radiological grading of the disease could differ on the basis of individual assessment. In the study presented here, when differences of opinion arose in Kellgren-Lawrence scoring, the two examiners reached a final decision together.

In conclusion, BMI correlated with pain and functional limitation in patients with OA of the knee. We found that these patients were not adequately advised on maintaining their ideal body weight and on regular physical exercising, subjects which require serious clinical attention. Radiological examination of the knee is used for the evaluation of $\mathrm{OA}$, but its use for assessing the severity of the disease is questionable. Therefore, clinicians should consider the individual patient's complaints rather than basing their opinion on the radiological imaging to determine the effective treatment and advice in the management of the disease.

\section{Conflict of Interest}

No conflict of interest is declared by authors.

\section{References}

1. Mankin H.J, Brandt K.D. Pathogenesis of osteoarthritis. In: Ruddy S, Haris ED, Sledge CB (eds). Kelley's Textbook of Rheumatology (vol II). Philadelphia, WB Saunders Company. 2001: 1391-407.

2. Ciombor DM, Aaron RK, Wang S, Simon B. Modification of osteoarthritis by pulsed electromagnetic field--a morphological study. Osteoarthr Cartilage 2003; 11: 455-62.

3. Woo J, Lau E, Lee P, Kwok T, Lau WC, Chan C, et al. Impact of osteoarthritis on quality of life in a Hong Kong Chinese population. J Rheumatol 2004; 31: 2433-8.

4. Merle-Vincent F, Couris CM, Schott AM, Perier M, Conrozier $\mathrm{S}$, Conrozier T, et al. Cross-sectional study of pain and disability at knee replacement surgery for osteoarthritis in 299 patients. Joint Bone Spine 2007; 74: 612-6.

5. Maly MR, Krupa T. Personal experience of living with knee osteoarthritis among older adults. Disabil Rehabil 2007; 29: 1423-33.

6. Altman R, Asch E, Bloch D, Bole G, Borenstein D, Brandt K, et al. Development of criteria for the classification and reporting of osteoarthritis. Classification of osteoarthritis of the knee. Diagnostic and Therapeutic Criteria Committee of the American Rheumatism Association. Arthritis Rheum 1986; 29: 1039-49.

7. Ravaud P, Auleley GR, Amor B, Dougados M. Radiographic assessment of progression in knee osteoarthritis. Rheumatol Europe 1995; 24: 129-31.

8. McConnell S, Kolopack P, Davis AM. The Western Ontario and McMaster Universities Osteoarthritis Index (WOMAC): A Review of Its Utility and Measurement Properties. Arthritis Care Res 2001; 45: 453-61.

9. Bellamy N, Buchanan WW, Goldsmith $\mathrm{CH}$, Campbell J, Stitt LW. Validation study of WOMAC: a health status instrument for measuring clinically important patient relevant outcomes to antirheumatic drug therapy in patients with osteoarthritis of the hip or knee. J Rheumatol1988; 15: 1833-40.

10. Tuzun EH, Eker L, Aytar A, Daskapan A, Bayramoglu M. Acceptability, reliability, validity and responsiveness of the Turkish version of WOMAC osteoarthritis index. Osteoarthr Cartilage. 2005; 13: 28-33.

11. Coggon $D$, Croft $P$, Kellingray $S$, Barrett $D$, McLaren $M$, Cooper C. Occupational physical activities and osteoarthritis of the knee. Arthritis Rheum 2000; 43: 1443-9.

12. Jarvholm B, Lewold S, Malchau H, Vingard E. Age, bodyweight, smoking habits and the risk of severe osteoarthritis in the hip and knee in men. Eur J Epidemiol 2005; 20: 537-42.

13. Yoshimura N, Nishioka S, Kinoshita H, Hori N, Nishioka T, Ryujin $M$, et al. Risk factors for knee osteoarthritis in Japanese women: heavy weight, previous joint injuries, and occupational activities. J Rheumatol 2004; 31: 157-62.

14. Mounach A, Nouijai A, Ghozlani I, Ghazi M, Achemlal L, Bezza A, et al. Risk factors for knee osteoarthritis in Morocco. A case control study.Clin Rheumatol. 2007; 3: 323-6.

15. Felson DT. Does excess weight cause osteoarthritis and, if so, why? Ann Rheum Dis 1996; 9: 668-70.

16. Davis MA, Neuhaus JM, Ettinger WH, Mueller WH. Body fat distribution. Am J Epidemiol1990; 4: 701-7.

17. Davies MA, Ettinger WH, Neuhaus JM. The role of metabolic factors and blood pressure in the association of obesity with osteoarthritis of the knee. J Rheumatol1998; 15: 1827-32.

18. Johnson SR, Archibald A, Davis AM, Badley E, Wright JG, Hawker GA. Is self-reported improvement in osteoarthritis 
pain and disability reflected in objective measures? J Rheumatol 2007; 34: 159-64.

19. Ding C, Martel-Pelletier J, Pelletier JP, Abram F, Raynauld JP, Cicuttini $F$, et al. Two-year prospective longitudinal study exploring the factors associated with change in femoral cartilage volume in a cohort largely without knee radiographic osteoarthritis. Osteoarthr Cartilage 2008; 16: 443-9.

20. Amin S, Niu J, Guermazi A, Grigoryan M, Hunter DJ, Clancy $\mathrm{M}$, et al. Cigarette smoking and the risk for cartilage loss and knee pain in men with knee osteoarthritis. Ann Rheum Dis 2007; 66: 18-22.

21. Felson DT, Anderson JJ, Naimark A, Hannan MT, Kannel BK, Meenan RF. Does smoking protect against osteoarthritis? Arthritis Rheum 1989; 32: 166-72.

22. Felson DT. The epidemiology of knee osteoarthritis: results from the Framingham Osteoarthritis Study. Semin Arthritis Rheum 1990; 20: 42-50.

23. Szoeke CE, Cicuttini FM, Guthrie JR, Clark MS, Dennerstein L. Factors affecting the prevalence of osteoarthritis in healthy middle-aged women: data from the longitudinal Melbourne Women's Midlife Health Project. Bone 2006; 39: 1149-55.

24. Järvholm B, Lewold S, Malchau H, Vingård E. Age, bodyweight, smoking habits and the risk of severe osteoarthritis in the hip and knee in men. Eur J Epidemiol 2005; 20: 537-42.

25. Gullahorn L, Lippiello L, Karpman R. Smoking and osteoarthritis: differential effect of nicotine on human chondrocyte glycosaminoglycan and collagen synthesis. Osteoarthr Cartilage 2005; 13: 942-3.

26. Wilder FV, Hall BJ, Barrett JP. Smoking and osteoarthritis: is there an association? The Clearwater Osteoarthritis Study. Osteoarthr Cartilage 2003; 11: 29-35.

27. Dieppe PA, Cushnaghan J, Shepstone L. The Bristol OA500 study: progression of osteoarthritis (OA) over 3 years and the relationship between clinical and radiographic changes at the knee joint. Osteoarthr Cartilage 1997; 5: 87-97.

28. Lethbridge-Cejku M, Scott WW Jr, Reichle R, Ettinger WH, Zonderman A, Costa $P$, et al. Association of radiographic features of osteoarthritis of the knee with knee pain: data from the Baltimore Longitudinal Study of Aging. Arthritis Care Res 1995; 8: 182-8.

29. Szebenyi B, Hollander AP, Dieppe P, Quilty B, Duddy J, Clarke $S$, et al. Associations between pain, function, and radiographic features in osteoarthritis of the knee. Arthritis Rheum 2006; 54: 230-5.

30. Claessens AA, Schouten JS, van den Ouweland FA. Do clinical findings associate with radiographic osteoarthritis of the knee? Ann Rheum Dis1990; 49: 771-4.

31. Davis MA, Ettinger WH, Neuhaus JM, Barclay JD, Segai MR. Correlates of knee pain among US adults with and without radiographic knee osteoarthritis. J Rheumatol 1992; 19: 1943-9.

32. Rupprecht TN, Oczipka F, Lüring C, Pennekamp PH, Grifka J. Is there a correlation between the clinical, radiological and intrasurgical findings of osteoarthritis of the knee? A Prospective study on 103 patients. Z Orthop Unfall 2007; 145: 430-5.

33. Torres L, Dunlop DD, Peterfy C, Guermazi A, Prasad P, Hayes $\mathrm{KW}$, et al.The relationship between specific tissue lesions and pain severity in persons with knee osteoarthritis. Osteoarthr Cartilage 2006; 14: 1033-40.

34. Keefe FJ, Affleck G, France CR, Emery CF, Waters S, Caldwell $D S$, et al. Gender differences in pain, coping, and mood in individuals having osteoarthritic knee pain: a within-day analysis. Pain 2004; 110: 571-7. 